\title{
Early Development of Electrical Excitability in the Mouse Enteric Nervous System
}

\author{
Marlene M. Hao, ${ }^{1}$ Alan E. Lomax, ${ }^{4}$ Sonja J. McKeown, ${ }^{1}$ Christopher A. Reid, ${ }^{3}$ Heather M. Young, ${ }^{1}$ and Joel C. Bornstein ${ }^{2}$ \\ ${ }^{1}$ Departments of Anatomy and Neuroscience and ${ }^{2}$ Physiology, University of Melbourne, and ${ }^{3}$ Florey Neuroscience Institutes, Melbourne, Victoria 3010, \\ Australia, and ${ }^{4}$ Department of Biomedical and Molecular Sciences, Queen's University, Kingston, Ontario K7L 3N6, Canada
}

Neural activity is integral to the development of the enteric nervous system (ENS). A subpopulation of neural crest-derived cells expresses pan-neuronal markers at early stages of ENS development (at E10.5 in the mouse). However, the electrical activity of these cells has not been previously characterized, and it is not known whether all cells expressing neuronal markers are capable of firing action potentials (APs). In this study, we examined the activity of “neuron"-like cells (expressing pan-neuronal markers or with neuronal morphology) in the gut of E11.5 and E12.5 mice using whole-cell patch-clamp electrophysiology and compared them to the activity of neonatal and adult enteric neurons. Around 30-40\% of neuron-like cells at E11.5 and E12.5 fired APs, some of which were very similar to those of adult enteric neurons. All APs were sensitive to tetrodotoxin (TTX), indicating that they were driven by voltage-gated $\mathrm{Na}^{+}$currents. Expression of mRNA encoding several voltage-gated $\mathrm{Na}^{+}$channels by the E11.5 gut was detected using RT-PCR. The density of voltage-gated Na ${ }^{+}$ currents increased from E11.5 to neonates. Immature active responses, mediated in part by TTX- and lidocaine-insensitive channels, were observed in most cells at E11.5 and E12.5, but not in P0/P1 or adult neurons. However, some cells expressing neuronal markers at E11.5 or E12.5 did not exhibit an active response to depolarization. Spontaneous depolarizations resembling excitatory postsynaptic potentials were observed at E12.5. The ENS is one of the earliest parts of the developing nervous system to exhibit mature forms of electrical activity.

\section{Introduction}

The enteric nervous system (ENS) is a complex network of neurons and glia within the wall of the gastrointestinal (GI) tract that regulates many aspects of GI function, including motility and secretion (Furness, 2006). All the neurons and glia of the ENS arise from neural crest cells, mostly from the vagal region of the neural tube, which migrate into and along the GI tract during development (Le Douarin and Teillet, 1973; Gershon, 2010; Sasselli et al., 2012). In mice, cells derived from the vagal neural crest enter the foregut at E9.5 and then colonize the gut in a rostral-to-caudal wave, reaching the caudal end of the colon at E14.5 (Kapur et al., 1992; Young and Newgreen, 2001).

Although the early events in ENS development, including proliferation and migration, have been intensively studied (Heanue and Pachnis, 2007), little is known about the mechanisms controlling the later events in ENS development including differentiation, axon guidance, and circuit formation (Gershon,

Received March 22, 2012; revised June 4, 2012; accepted June 19, 2012.

Author contributions: M.M.H., A.E.L., C.A.R., H.M.Y., and J.C.B. designed research; M.M.H., A.E.L., and S.J.M. performed research; M.M.H. analyzed data; M.M.H., A.E.L., C.A.R., H.M.Y., and J.C.B. wrote the paper.

This work was supported by Australian Research Council Discovery Grant DP0878755 (H.M.Y. and J.C.B.). We thank Dr. Ernest Jennings (James Cook University, Australia) for help with patch-clamp experimental technique, Dr. John Furness (University of Melbourne, Australia) for assistance with equipment, Dr. Kazuto Kobayashi (Fukushima University, Fukushima, Japan) for providing the TH-GFP mice, and Dr. Vanda Lennon (Mayo Clinic, USA) for providing the Hu antiserum.

The authors declare no competing financial interests.

Correspondence should be addressed to Dr. Joel C. Bornstein, Department of Physiology, University of Melbourne, Parkville, Victoria 3010, Australia. E-mail: j.bornstein@unimelb.edu.au.

DOI:10.1523/JNEUROSCI.1426-12.2012

Copyright $\odot 2012$ the authors $\quad 0270-6474 / 12 / 3210949-12 \$ 15.00 / 0$
2010). It was shown over 20 years ago that a subpopulation of enteric neural crest-derived cells (ENCCs) expresses pan-neuronal markers soon after they first enter the gut at E10.5 (Baetge and Gershon, 1989). Data from several subsequent studies strongly suggest that enteric neurons are electrically excitable at prenatal stages, as genetic deletion of some neurotransmitter synthetic enzymes or transporters (Li et al., 2010, 2011) or blocking electrical activity in explants of embryonic gut (Vohra et al., 2006; Hao et al., 2010) result in defects in ENS development. We recently showed that a subpopulation of cells expressing neuronal markers in the gut of E11.5 mice respond to electrical field stimulation with an increase in intracellular $\mathrm{Ca}^{2+}$ (Hao et al., 2011). Action potentials (APs) were recorded from a small number of cells at E12.5. However, the events preceding the development of APs have not been examined, nor have the AP firing properties of embryonic neurons been compared with those of adult enteric neurons. Furthermore, the development of the expression of voltage-gated ion channels required to fire APs at these time points has never been explored. Knowledge of these fundamental characteristics of cells is central to our understanding of how neuronal circuits develop in the gut. Also, these characteristics potentially form a template on which we can track successful differentiation of enteric neurons from stem/progenitor cells in studies investigating the potential of cell therapy for diseases of the ENS.

Here, we investigated the emergence of electrical excitability in the developing ENS of mice using whole-cell patch-clamp recordings from acutely dissociated cells. Our data show that some cells expressing neuronal markers in the E11.5 and E12.5 gut fire 
APs with similar properties to adult enteric neurons, but many neuron-like cells at these ages respond to electrical stimulation with a less mature, but active, increase in membrane potential, while a small proportion lack any active response to depolarization.

\section{Materials and Methods}

Animals. Mice on a C57BL/6J background were used for all experiments. For E11.5 studies, mice in which GFP expression is driven by the tyrosine hydroxylase (TH) promoter were used (TH-GFP mice) (Sawamoto et al., 2001). Pregnant females were killed by $\mathrm{CO}_{2}$ followed by cervical dislocation. The embryos were quickly removed and immediately decapitated before dissection, as approved by the Anatomy and Cell Biology, Neuroscience, Pathology, Pharmacology and Physiology Animal Ethics Committees of the University of Melbourne.

Tissue dissociation and short-term culture. Embryos were dissected in sterile DMEM/F12. The gut was removed and dissociated in collagenase/dispase $(2 \mathrm{mg} / \mathrm{ml}$; with $0.1 \mathrm{U} / \mathrm{mg}$ for collagenase and $0.8 \mathrm{U} / \mathrm{mg}$ for dispase; Roche) in culture media (DMEM/F12 supplemented with $10 \%$ FBS, $200 \mathrm{~mm}$ L-glutamine, $100 \mathrm{U}$ penicillin/streptomycin; all reagents from Sigma) for $15-20 \mathrm{~min}$ at $37^{\circ} \mathrm{C}$, followed by gentle trituration. The entire gut caudal to the stomach was dissected from E11.5 heterozygous TH-GFP embryos. At E12.5, only the small intestine was prepared for culture. For $\mathrm{P} 0 / \mathrm{P} 1$ cultures, the duodenum (rostral $1 / 3$ of the small intestine) was dissected from either P0 or P1 mouse pups in sterile DMEM/F12, dissociated in collagenase/dispase $(2 \mathrm{mg} / \mathrm{ml}$ in culture media) for $1 \mathrm{~h}$ and triturated. Adult (male and female mice between 2-10 months of age) duodenum was dissected in sterile Krebs (in mм: $120.9 \mathrm{NaCl}, 5.9 \mathrm{KCl}, 1.2 \mathrm{MgCl}_{2}$, $2.5 \mathrm{CaCl}_{2}, 1.2 \mathrm{NaH}_{2} \mathrm{PO}_{4}, 14.4 \mathrm{NaHCO}_{3}, 11.5$ glucose). The mucosa, submucosal, and circular muscle were removed, leaving the longitudinal muscle and myenteric plexus, which was dissociated in collagenase/dispase $(2 \mathrm{mg} / \mathrm{ml}$ in culture media) for $1 \mathrm{~h}$ and triturated. All cells were plated on glass coverslips in culture media. Embryonic and P0/P1 cells were cultured for $2-10 \mathrm{~h}$ before recording, to minimize further maturation of the neurons. Adult neurons were cultured for 4-24 h.

Whole-cell patch-clamp electrophysiology. Cells were visualized on a Zeiss Axiovert25 microscope using both bright-field and fluorescence optics. Cells were superfused with HEPES-buffered saline (in mM: $140 \mathrm{NaCl}, 5 \mathrm{KCl}, 10 \mathrm{HEPES}, 2 \mathrm{CaCl}_{2}$, $2 \mathrm{MgCl}_{2}$, and $10 \mathrm{D}$-glucose, adjusted to $\mathrm{pH}=7.4$ using $\mathrm{NaOH}$ ). Patch pipettes were pulled from borosilicate glass capillaries (Harvard Apparatus) using a P-97 puller (Sutter Instruments). Pipette resistance was $\sim 10 \mathrm{~m} \Omega$ when filled with a potassium methanesulfonate internal solution, adapted from the study by Mao et al. (2006) (in $\mathrm{mm}: 115 \mathrm{KMeSO}_{3}, 9 \mathrm{NaCl}, 10 \mathrm{HEPES}, 0.1$ $\mathrm{CaCl}_{2}, 1 \mathrm{MgCl}_{2}, 0.2$ BAPTA.K, $2 \mathrm{Mg}$-ATP, and $0.25 \mathrm{Na}$-GTP). Pipette capacitance was compen-
A
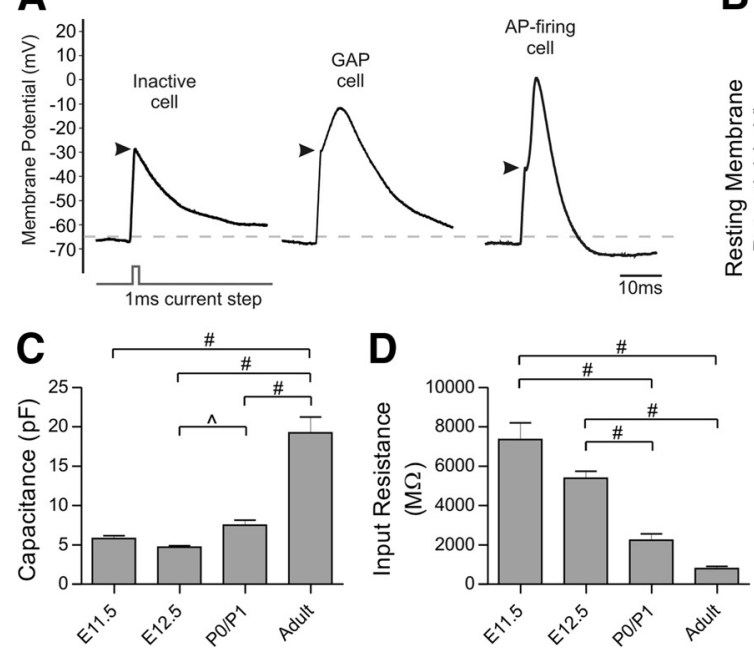

B
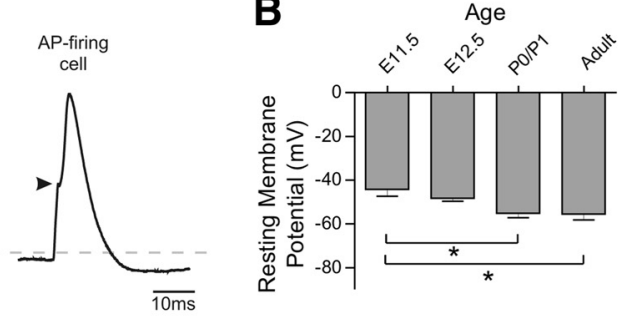

Figure 1. $\boldsymbol{A}$, Representative responses of $\mathrm{E} 11.5 \mathrm{TH}_{\mathrm{GFP}}{ }^{+}$cells to $1 \mathrm{~ms}$ depolarizing current stimulation. The depolarizing current produced an initial passive increase in membrane potential in all cells (arrowheads). "Inactive" cells (19\% of TH-GFP ${ }^{+}$cells) did not produce an active increase in membrane potential response to the depolarizing current, and their membrane potential decayed passively to baseline following the initial depolarization. Eighty-one percent of TH-GFP ${ }^{+}$cells were classified as "electrically active" as they exhibited an active response to the $1 \mathrm{~ms}$ depolarizing current stimulation; this included both "GAP-generating" cells, which produced a small active response (with a maximum rate of rise $<20 \mathrm{mV} / \mathrm{ms}$ ), and "AP-firing" cells, which fired all-or-nothing APs. $\boldsymbol{B}-\boldsymbol{E}$, Changes in the membrane properties of electrically active ENCCs through different stages of development (mean \pm SEM, $n$-numbers shown on graphs). Differences were observed in the cells' RMP $(\boldsymbol{B})$, capacitance $(\boldsymbol{C})$, input resistance $(\boldsymbol{D})$, and membrane time constants $(\boldsymbol{E})$ at various stages of development. ${ }^{*} p<0.05 ;{ }^{\wedge} p<0.01$; ${ }^{\#} p<0.001$; Kruskal-Wallis with Dunn's post hoc test for all, except cell capacitance $(\boldsymbol{C})$, which was analyzed using one-way ANOVA followed by Bonferroni post hoc test.

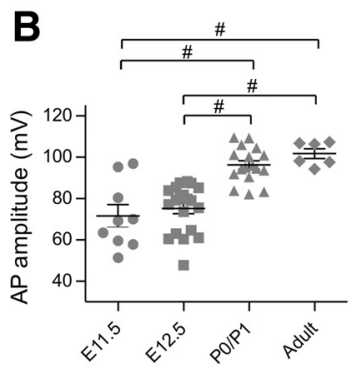

B'
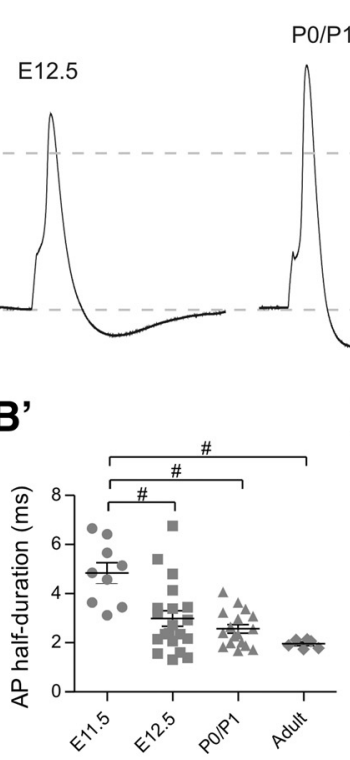

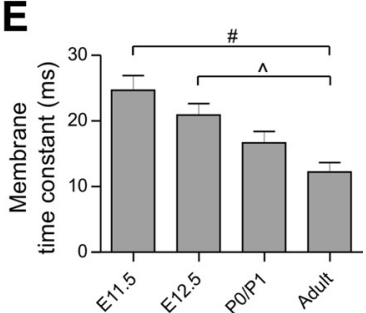

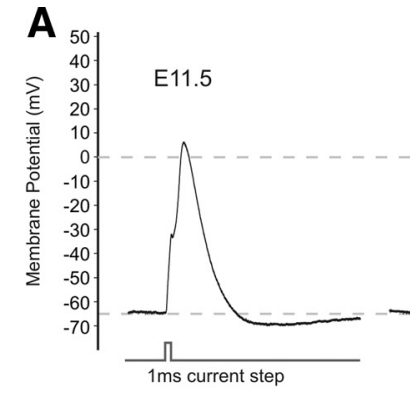
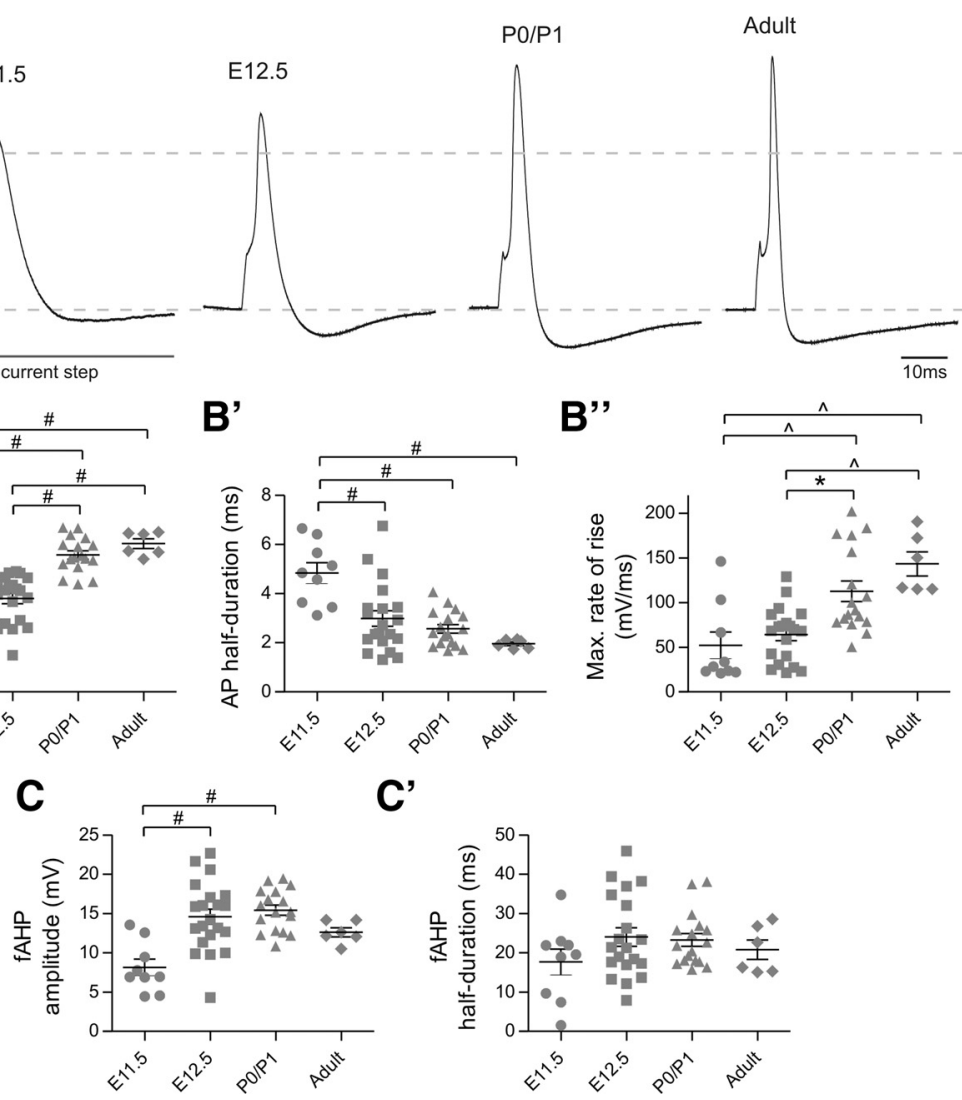

C'
B"

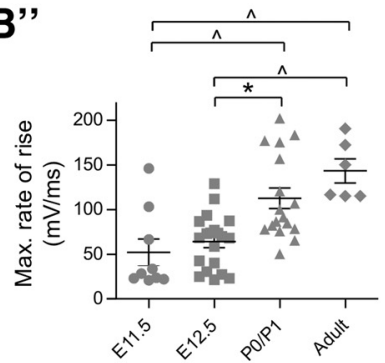

Figure 2. Changes in APs through development. Typical APs from each age are shown in $\boldsymbol{A}$, stimulated from a baseline membrane potential of $-65 \mathrm{mV}$ using a $1 \mathrm{~ms}$ depolarizing current step. Differences in AP amplitude $(\boldsymbol{B})$, half-duration $\left(\boldsymbol{B}^{\prime}\right)$, and maximum rate of rise $\left(\boldsymbol{B}^{\prime \prime}\right)$ were observed at various ages. fAHP amplitude $(\boldsymbol{C})$ was smaller at E11.5, but fAHP amplitude $\left(\boldsymbol{C}^{\prime}\right)$ was not different between any of the ages $\left({ }^{*} p<0.05 ;{ }^{\wedge} p<0.01\right.$; ${ }^{\#} p<0.001$; one-way ANOVA followed by Bonferroni post hoc test for all except maximum rate of rise $\left(\boldsymbol{B}^{\prime \prime}\right)$, which was analyzed using Kruskal-Wallis with Dunn's post hoc test). 
sated before whole-cell recording. All recordings were made at $33^{\circ} \mathrm{C}$ using an Axopatch 200B amplifier and pCLAMP9 software (both from Molecular Devices). Data were acquired at $50 \mathrm{kHz}$ and filtered at $2 \mathrm{kHz}$. Liquid junction potentials were calculated using JPCalcW (Molecular Devices) and corrected offline. All data were analyzed using Clampfit (Molecular Devices).

Membrane potential measurements. APs were stimulated in currentclamp mode. Membrane potential was adjusted to $\sim-65 \mathrm{mV}$ and cells depolarized with a series of $1 \mathrm{~ms}$ current pulses in 10 or $50 \mathrm{pA}$ increments until APs were stimulated. The amplitude of APs was measured from the baseline membrane potential to the peak of the AP, and the half-duration was measured as the duration at half this amplitude. APs were usually followed by a fast afterhyperpolarizing potential (fAHP), the amplitude of which was also measured from the baseline membrane potential. The maximum rate of rise of an AP was calculated as the peak of its first time derivative. An active change in membrane potential evoked during current injections that could not be classified as an $\mathrm{AP}$ was observed in some cells, and were termed "graded active potentials" (GAPs). The amplitudes and time courses of GAPs were calculated by subtracting the theoretically predicted passive decay of the imposed depolarization from the actual record (see Fig. $7 A^{\prime}$ ). The passive decay was predicted using the membrane time constant calculated from the initial membrane potential change produced by a $\geq 200 \mathrm{~ms}$ hyperpolarizing current step. Small hyperpolarizing steps (where membrane potential change was $<20 \mathrm{mV}$ ) were used to ensure a passive response.

Properties of voltage-gated conductances. Inward and outward currents were examined in voltage-clamp mode with series resistance compensation applied. Cells were held at $-70 \mathrm{mV}$ and a series of $100 \mathrm{~ms}$ voltage steps were applied with $10 \mathrm{mV}$ increments at $5 \mathrm{~s}$ intervals for embryonic neurons, and $20 \mathrm{~s}$ intervals for adult neurons to ensure there was no interference from the current of the slow afterhyperpolarizing potential (sAHP). The peak current amplitude at each voltage was normalized to cell capacitance to produce current-voltage plots.

The reversal potential of the inward current for each individual cell was determined using the current-voltage plot for that cell. A linear regression line was fitted to the current-voltage plot for the points where $-10 \mathrm{mV} \leq V_{\text {step }} \leq+30 \mathrm{mV}$ for each cell, where $V_{\text {step }}$ is the step potential. The reversal potential was calculated by extrapolating this line to the membrane potential where current equals $0 \mathrm{pA}$. The theoretical reversal potentials were calculated for $\mathrm{Na}^{+}$and $\mathrm{Ca}^{2+}$ using the Nernst equation, as follows:

$$
V_{\text {rev }}=\frac{R T}{z F} \ln \left(\frac{[\text { ion }]_{\text {out }}}{[\text { ion }]_{\text {in }}}\right)
$$

where $V_{\text {rev }}$ is the reversal potential, $R$ the universal gas constant, $T$ the temperature, $z$ the valence of the ionic species, and $F$ the Faraday's constant. The concentrations of these ions in the pipette and bath solutions (with $\mathrm{Ca}^{2+}$ buffers accounted for) were fitted to the equation, and the theoretical reversal potential was calculated to be $+70 \mathrm{mV}$ for $\mathrm{Na}^{+}$and $+125 \mathrm{mV}$ for $\mathrm{Ca}^{2+}$.

To assess the voltage dependence of current activation, the conductance $(G)$ was first calculated from the peak current $\left(I_{\text {peak }}\right)$ at each step potential:

$$
G=\frac{I_{\text {peak }}}{\left(V_{\text {step }}-V_{\text {rev }}\right)},
$$

with $V_{\text {rev }}$ calculated for each cell using the method above. Normalized conductance-voltage curves were then fitted to the Boltzmann function:

$$
\frac{G}{G_{\max }}=\frac{1}{1+\mathrm{e}^{\left(V_{1 / 2}-V\right) / k}},
$$

where $V_{1 / 2}$ is the voltage of half-activation, and $k$ is the slope factor (Hodgkin and Huxley, 1952; Hille, 2001).

Expression of voltage-gated $\mathrm{Na}^{+}$channels using RT-PCR. Total RNA was isolated from the following tissues using a Qiagen RNeasy mini kit, and genomic DNA contamination was removed using on-column DNase digestion, according to the manufacturer's instruction. Tissues examined were wild-type E11.5 gut (entire gut caudal to the stomach), adult gut

\section{A E11.5}
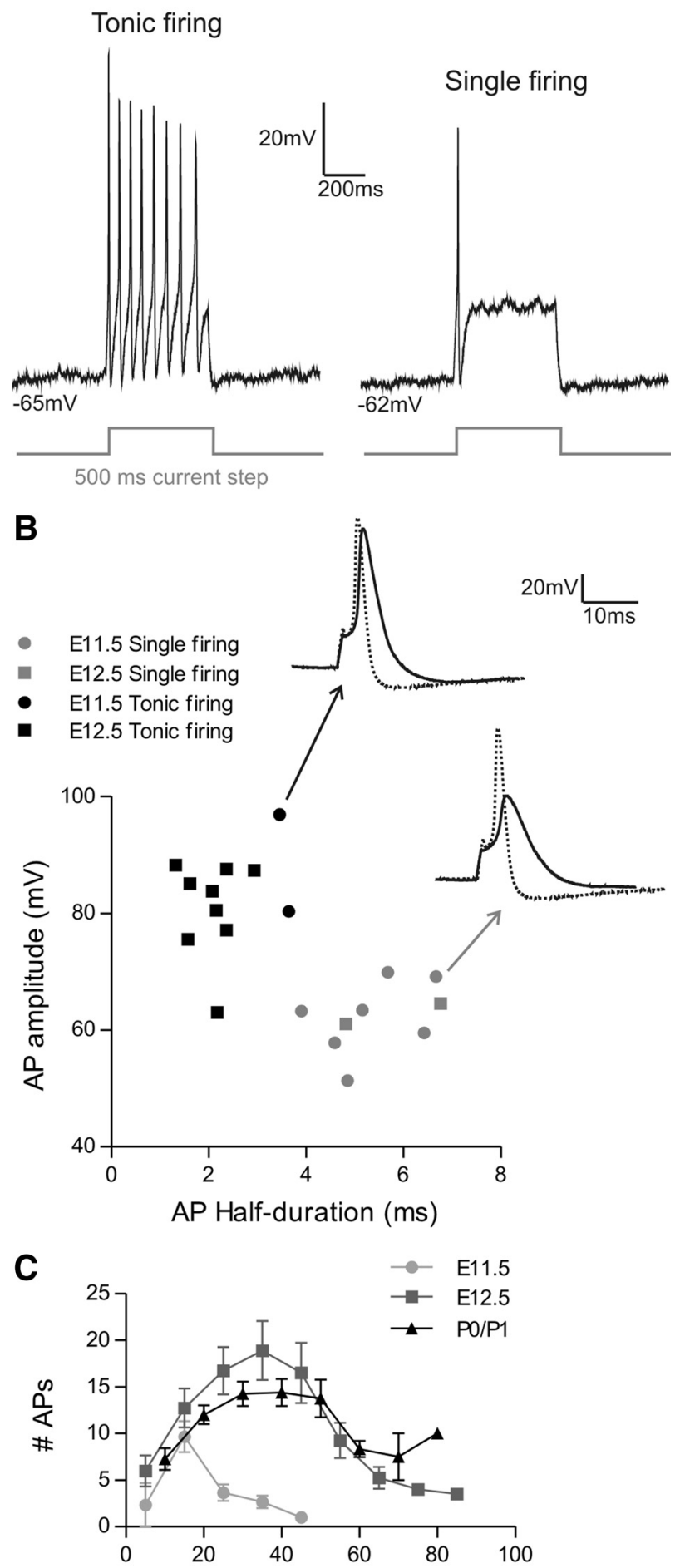

Current step $(\mathrm{pA})$

Figure 3. Tonically firing neurons at E11.5 and E12.5 have more adult-like AP properties than single firing neurons. $\boldsymbol{A}$, Typical traces of responses to a $500 \mathrm{~ms}$ depolarizing current step from E11.5 cells. $B$, Examination of AP properties when stimulated with a $1 \mathrm{~ms}$ depolarizing current step from a baseline membrane potential of $-65 \mathrm{mV}$. Cells with larger amplitude and smaller half-duration were identified to be tonically firing. Single firing cells had a smaller amplitude and larger half-duration. Insets show examples of E11.5 APs from a tonically firing cell (top left, solid trace) and a single firing cell (bottom right, solid trace) compared with an adult AP (dotted trace). C, Comparison of the number of APs fired by tonically firing cells in response to increasing current steps. 
(myenteric plexus with attached circular and longitudinal muscle layers from the duodenum), and adult brain tissues (entire brain). The concentration of RNA in each sample was measured using a NanoDrop ND-1000 spectrophotometer (Biolab). cDNA was synthesized using Omniscript reverse transcriptase (Qiagen), using 400-600 ng of total RNA in a $20 \mu \mathrm{l}$ reaction mix and oligo-dT primers $(1 \mu \mathrm{M}$, Invitrogen) according to the manufacturer's instruction. Intron-spanning specific primer pairs were used to amplify $\mathrm{Na}_{\mathrm{V}}$ genes: $\mathrm{Na}_{\mathrm{V}} 1.3$ forward (fwd) 5 '-tgccaaggagtggaggaa, reverse (rev) $5^{\prime}$-agt ctctcctgctctcgc, 345bp (Vignali et al., 2006); $\mathrm{Na}_{\mathrm{V}} 1.5$ fwd 5' -cacggttcgaggaagacaag, rev 5' -aggt ctgcggtgttggtcat, $380 \mathrm{bp}$ (Kerr et al., 2004); $\mathrm{Na}_{\mathrm{V}} 1.6$ fwd 5' -aggctctccgaggagctca, rev 5' -gtgctgttgcgttt cacgct, 513bp (Vignali et al., 2006); $\mathrm{Na}_{\mathrm{V}} 1.7$ fwd $5^{\prime}$-tcttcagaaacctccaggct, rev 5' -ggggtctatggggtaca aa, 397bp (Vignali et al., 2006); $\mathrm{Na}_{\mathrm{V}} 1.9$ fwd $5^{\prime}$-ag cagcggagcactgatatt, rev 5'-gcagaccagcaagacattga, $351 \mathrm{bp}$ (designed by us).

Twenty to thirty nanograms of total RNA was used in each 32 cycle reaction for $\mathrm{Na}_{\mathrm{V}} 1.3$, $\mathrm{Na}_{\mathrm{V}} 1.6$, and $\mathrm{Na}_{\mathrm{V}} 1.9$, while $40-60 \mathrm{ng}$ of total RNA was used in each 35 cycle reaction for $\mathrm{Na}_{\mathrm{V}} 1.5$ and $\mathrm{Na}_{\mathrm{V}}$ 1.7. RT-PCR was performed using a standard PCR protocol with optimum annealing temperatures for each primer set. Control reactions using no reverse transcriptase were run in parallel for each tissue and primer set. PCR products were resolved by gel electrophoresis, using Easyladder I (Bioline) to estimate PCR product size.

Immunohistochemistry. Cells cultured on coverslips for 4 or $7 \mathrm{~h}$ were fixed in $4 \%$ paraformaldehyde in $\mathrm{PBS}$ at $4^{\circ} \mathrm{C}$ overnight, permeabilized in $1 \%$ Triton X-100 (in PBS) and incubated in the following primary antisera for $24 \mathrm{~h}$ at $4^{\circ} \mathrm{C}$ : rabbit anti-synaptophysin (1: 1000; DAKO); mouse anti-neuronal class III $\beta$-tubulin (Tuj1; 1:2000; Covance); and human anti-Hu [1:5000; gift from Dr. Vanda Lennon, Mayo Clinic, Rochester, MN (Fairman et al., 1995)]. After washing, secondary antibodies were applied for $2 \mathrm{~h}$ at room temperature: donkey anti-rabbit FITC (1:200; Jackson Laboratories); donkey anti-mouse Alexa 647 (1:500; Invitrogen); and donkey anti-human Texas Red (1:100; Jackson ImmunoResearch). Cells were imaged with a Zeiss Pascal confocal microscope using a $\times 63$, $1.4 \mathrm{NA}$ objective lens, and were imaged at $1024 \times 1024$ pixels per frame. Images were taken as single optical sections with a pinhole setting of 1 Airy unit.

Data presentation and statistical analysis. All population data, including graphs, are presented as mean \pm SEM, unless otherwise stated. Statistical analyses were performed with Prism (GraphPad Software). The Kolmogorov-Smirnov test was used to examine whether data followed a normal distribution. For normally distributed datasets, one-way ANOVA (with Bonferroni post hoc test) or the Student's $t$ test was applied. For data that were not normally distributed, Kruskal-Wallis (followed by Dunn's post hoc test) or Mann-Whitney tests were applied. Current-voltage relations were compared by two-way ANOVA, followed by Bonferroni post hoc test. Differences were considered to be significant if $p<0.05$.

\section{Results}

Electrophysiological properties of embryonic, early postnatal, and adult enteric neurons

Whole-cell patch-clamp recordings were made from cells in short-term cultures of E11.5, E12.5, P0/P1, and adult gut. To identify cells expressing pan-neuronal markers in E11.5 cultures, cells from TH-GFP mice were used, as the subpopulation of ENCCs that expresses pan-neuronal markers transiently express $\mathrm{TH}$ at this age (Sawamoto et al., 2001; Hao et al., 2009). By E12.5, $\mathrm{TH}$ is downregulated in cells expressing pan-neuronal markers. However, cells with the morphological characteristics of neurons

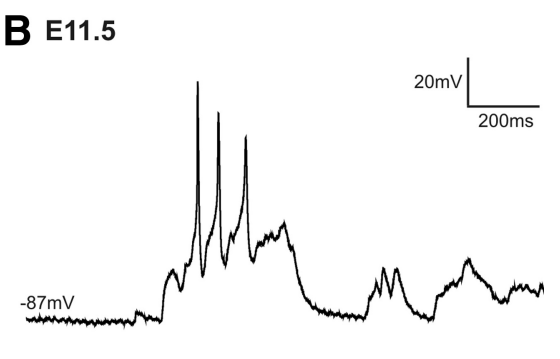

$C_{\text {E12.5 }}$

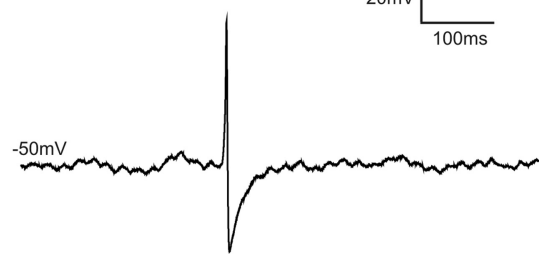

were readily identifiable in preparations of E12.5, P0/P1, and adult cultures, as described previously (Hao et al., 2011). Recordings were made from cells taken from rostral regions of the intestine at each age as there is a rostral-to-caudal progression in the maturation of ENCCs (Hao et al., 2011); however, the entire gut was taken at E11.5 as there is only a small number of ENCCs in the postcaecal gut at this age (Young and Newgreen, 2001). The majority of TH-GFP ${ }^{+}$cells at E11.5 and cells with neuron-like morphology at E12.5 responded to a $1 \mathrm{~ms}$ depolarizing current pulse with an active membrane potential depolarization (81\%, $n=41$ for E11.5; and 93\%, $n=84$ for E12.5; Fig. $1 A$ ). In these cells, the $1 \mathrm{~ms}$ depolarizing current pulse $(128 \pm 6 \mathrm{pA}, n=85)$ produced an initial passive increase in membrane potential to between $-40 \mathrm{mV}$ and $-20 \mathrm{mV}$ (Fig. $1 \mathrm{~A}$ ). Responses were classified as active when the membrane potential increased beyond this initial passive depolarization (Fig. $1 A$ ). The remaining population were considered to be "inactive" cells (Fig. 1A), as their membrane potentials decayed passively back to baseline after the $1 \mathrm{~ms}$ depolarizing pulse; no active depolarization response could be elicited in these cells even when the membrane potential was depolarized to $0 \mathrm{mV}$.

Active responses with a rate of rise $>20 \mathrm{mV} / \mathrm{ms}$ were classified as APs, as the majority of these responses in embryonic cells $(n=$ $21 / 28$ ) overshot $0 \mathrm{mV}$ when stimulated from a baseline membrane potential of $-65 \mathrm{mV}$ (Fig. $2 A, B)$. All P0/P1 $(n=17)$ and adult $(n=16)$ cells with neuron-like morphology fired APs, whereas only $43 \%$ of TH-GFP ${ }^{+}$cells at E11.5 and $29 \%$ cells with neuronal morphology at E12.5 fired APs. However, the proportion of AP-firing cells at E11.5 may not be representative of the population, as cells with the brightest GFP fluorescence were selected for recording. Most active responses exhibited by E11.5 and E12.5 cells were much smaller in amplitude and longer in duration than APs, and were termed graded active potentials (GAPs) to distinguish them from all-or-nothing APs. A description of the AP characteristics of 28 AP-firing cells from E12.5 mice has been published previously (Hao et al., 2011). However, qualitative criteria were used in the previous study to select cells that fired APs, rather than the quantitative criteria described here. In the current study, we have reanalyzed the membrane potential properties of cells used for the previous publication on 
E12.5 cells, and combined it with an additional 56 cells from E12.5 mice for comparison with E11.5, postnatal, and adult neurons.

The passive membrane properties of cells with active responses to $1 \mathrm{~ms}$ depolarization changed with developmental age. Cell capacitance was low at E11.5 and E12.5, increased at P0/P1, and in adults (Fig. 1C). The resting membrane potential (RMP) was significantly more depolarized at E1 1.5 compared with $\mathrm{P} 0 / \mathrm{P} 1$ and adult neurons (Fig. $1 B$ ). At RMP, the input resistance was highest at E11.5 and decreased significantly during development (Fig. 1D). The membrane time constants were significantly higher at E11.5 and E12.5 than in adult neurons (Fig. 1E).

\section{Changes in AP firing properties through development}

The properties of APs (i.e., responses with rate of rise $>20 \mathrm{mV} /$ ms) changed during development (Fig. $2 \mathrm{~A}$ ). Although the adult neurons in this study could be subdivided into two electrophysiological classes, the after-hyperpolarizing $(\mathrm{AH})$ and synaptic (S) classes typically used in studies of the adult ENS (Hirst et al., 1974; Bornstein et al., 1994), we have grouped the adult AH and S neuron data to make comparisons to younger ages, where APfiring cells could not be clearly classified into either electrophysiological subtype (see below). All recordings of APs were performed with cells held at $-65 \mathrm{mV}$. The amplitudes of APs at E11.5 and E12.5 were significantly smaller than those of P0/P1 and adult (Fig. $2 B$ ). The half-durations of E11.5 APs were significantly larger than that of E12.5, P0/P1, and adult APs (Fig. $2 B^{\prime}$ ), but did not differ between E12.5 and older ages. The maximum rates of rise of the AP were also significantly lower for E11.5 and E12.5 neurons than for P0/P1 and adult neurons (Fig. $2 B^{\prime \prime}$ ). The amplitudes of the fast afterhyperpolarizing potentials (fAHPs) were smaller at E11.5 than at E12.5 and at P0/P1, but did not differ from adult neurons (Fig. 2C). fAHP half-durations did not differ significantly over the four ages (Fig. $2 C^{\prime}$ ). No significant differences were seen between P0/P1 and adult APs, indicating that the characteristics of APs are already mature by $\mathrm{P} 0 / \mathrm{P} 1$.

Although the properties of embryonic APs were more immature overall, with smaller amplitudes and longer durations than adult APs, some E11.5 and E12.5 cells fired APs that were indistinguishable from those of $\mathrm{P} 0 / \mathrm{P} 1$ and adult neurons (Figs. 2, 3B). This was also reflected in their ability to fire trains of APs in response to a longer duration $(500 \mathrm{~ms})$ depolarizing pulse (Fig. $3 B$ ). Most E11.5 cells only fired a single AP at the beginning of a $500 \mathrm{~ms}$ pulse $(n=6 / 9)$, but three cells fired repetitively throughout the depolarization (tonic firing; Fig. $3 A$ ). At E12.5 and P0/P1, the majority of cells fired tonically $(n=9 / 11$ and $n=12 / 16$, respectively). At both E11.5 and E12.5, the tonically firing cells were those that fired adult-like APs, and the single firing cells those with immature APs (Fig. 3B). Thus, it appears that neurons acquire the ability to fire tonically as they mature. The voltage dependence of tonic firing was examined for each age group by depolarizing cells with a series of increasing current pulses (Fig. $3 C$ ). In E12.5 and P0/P1 cells, the number of APs initially increased with increased current, but then decreased after reaching a peak, whereas E11.5 neurons only fired trains of APs in response to smaller current steps.

Spontaneous APs were recorded from several P0/P1 neurons $(n=6 / 17)$ as well as adult neurons $(n=6 / 16)$ at their RMP. In P0/P1 neurons, spontaneous APs usually occurred as bursts (Fig. $4 A$ ), whereas in adults, they typically appeared as single events. Spontaneous APs were also recorded from AP-firing cells at both E11.5 ( $n=3 / 13$ AP-firing cells; Fig. $4 B)$ and E12.5 $(n=3 / 24$ AP-firing cells; Fig. 4C).
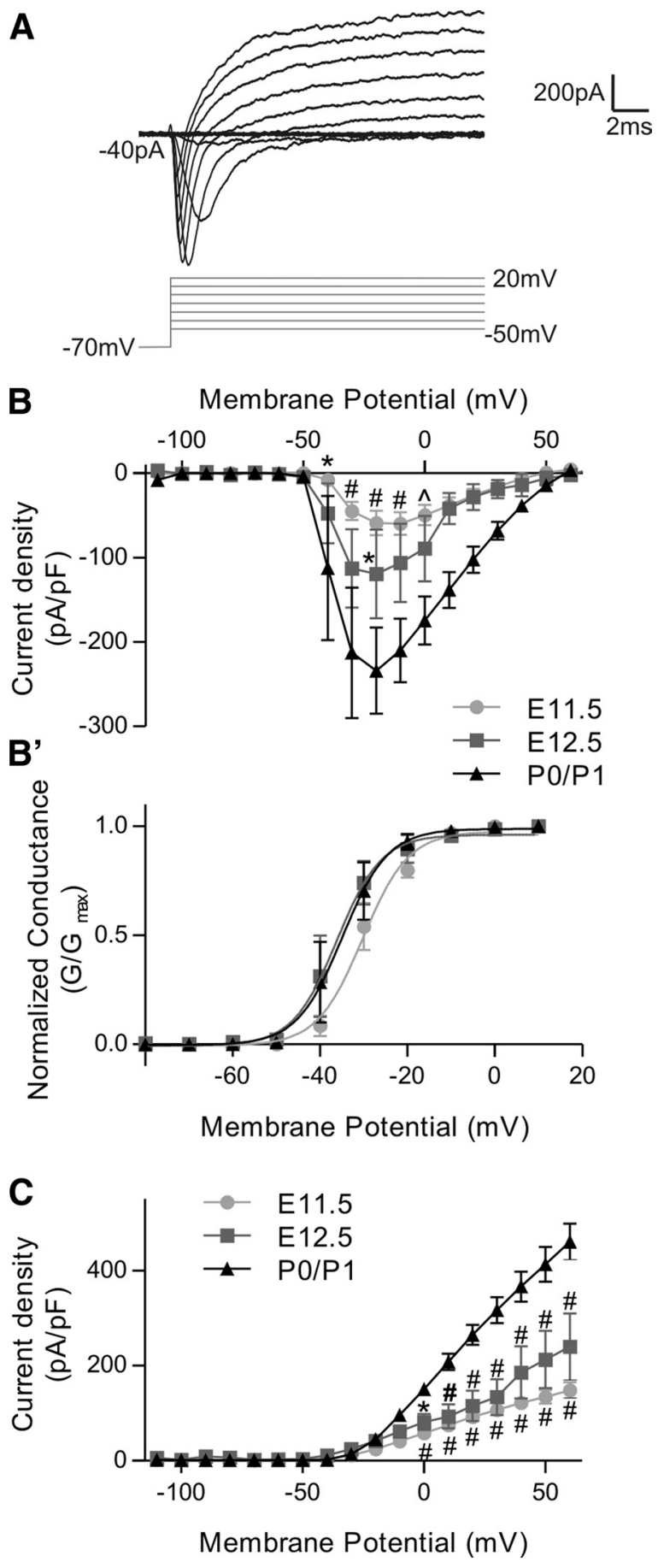

Figure 5. Inward $\left(\mathrm{Na}^{+}\right)$and outward $\left(\mathrm{K}^{+}\right)$currents. $A$, Representative traces of inward and outward currents recorded in voltage-clamp from an E11.5 AP-firing cell when depolarized from a holding potential of $-70 \mathrm{mV}$. $\boldsymbol{B}$, Average current-voltage relationships of the inward $\mathrm{Na}^{+}$ current in E11.5, E12.5, and P0/P1 AP-firing cells. Current densities were significantly lower at E11.5 and E12.5 compared with P0/P1. $\boldsymbol{B}^{\prime}$, The voltage dependence of activation of the $\mathrm{Na}^{+}$ current. $C, K^{+}$current density was also lower at E11.5 and E12.5 compared with P0/P1. $n=4$ for E11.5, $n=4$ for E12.5, $n=3$ for P0/P1; ${ }^{*} p<0.05,{ }^{\wedge} p<0.01,{ }^{\#} p<0.0001$; two-way ANOVA followed by Bonferroni post hoc test for all.

\section{The development of voltage-gated $\mathrm{Na}^{+}$and $\mathrm{K}^{+}$currents}

Voltage-clamp studies were performed to investigate the development of voltage-gated $\mathrm{Na}^{+}$and $\mathrm{K}^{+}$currents between E11.5 and $\mathrm{P} 0 / \mathrm{P} 1$. When depolarized from a holding potential of -70 $\mathrm{mV}$, a fast, inward current was observed in AP-firing cells at $\mathrm{E} 11.5, \mathrm{E} 12.5$, and $\mathrm{P} 0 / \mathrm{P} 1$, which presumably reflected the influx of 
$\mathrm{Na}^{+}$through voltage-gated $\mathrm{Na}^{+}$channels (VGSCs; Fig. 5A). This was followed by a slowly activating, non-inactivating, outward current (Fig. 5A). The current-voltage relationship of the inward current was very similar in AP-firing cells at all three ages, although embryonic cells had significantly lower current densities compared with P0/P1 neurons (Fig. 5B). The reversal potential of this current was calculated for all AP-firing cells, and was found to be $+45 \pm 5.8 \mathrm{mV}, n=4 ;+46 \pm 3.9 \mathrm{mV}, n=$ 4 ; and $+49 \pm 1.7 \mathrm{mV}, n=3$, for E11.5, $\mathrm{E} 12.5$, and $\mathrm{P} 0 / \mathrm{P} 1$ cells, respectively. These values are similar to the calculated theoretical reversal potential for $\mathrm{Na}^{+}$, which is $+70 \mathrm{mV}$. The voltage dependence of activation of the inward current was very similar at all three ages (Fig. 5 $B^{\prime}$ ). When fitted with the Boltzmann's function, there was no significant difference between the voltage of half-activation $(-30 \pm 2.3 \mathrm{mV}, n=4 ;-35 \pm 3.1 \mathrm{mV}, n=4$; and $-35 \pm 3.4 \mathrm{mV}$, $n=3$, respectively; $p=0.52)$ or the slope factor $(4.3 \pm 0.4 ; 4.0 \pm$ 1.2; and $3.5 \pm 0.7 ; p=0.8$ ) for E11.5, E12.5, and P0/P1 AP-firing cells (Kruskal-Wallis test for both).

The amplitude of the outward current, which exhibited a current-voltage relationship that was typical of voltage-gated $\mathrm{K}^{+}$ conductances, also increased through development. The current-voltage relationship for this current exhibited pronounced outward rectification at all three ages (Fig. 5C). The current density was again higher at P0/P1 than in E11.5 and E12.5 AP-firing cells (Fig. 5C).

\section{Expression of voltage-gated $\mathrm{Na}^{+}$channels in E11.5 gut}

The expression of several genes encoding different VGSCs $\left(\mathrm{Na}_{\mathrm{V}} 1.3, \mathrm{Na}_{\mathrm{V}} 1.5, \mathrm{Na}_{\mathrm{V}} 1.6, \mathrm{Na}_{\mathrm{V}} 1.7\right.$, and $\left.\mathrm{Na}_{\mathrm{V}} 1.9\right)$ by the E11.5 gut was examined using RT-PCR. The adult duodenum and adult brain were used as positive controls. Transcripts encoding all five VGSCs were detected at E11.5 (Fig. 6). Expression of each of these transcripts was also detected in the adult duodenum, and all except $\mathrm{Na}_{\mathrm{V}} 1.9$ in the adult brain (Fig. 6). The primers designed against $\mathrm{Na}_{\mathrm{V}} 1.5$ detected several alternatively spliced isoforms. The $\mathrm{Na}_{\mathrm{V}} 1.5 / \mathrm{Na}_{\mathrm{V}} 1.5 \mathrm{c}$ isoform of $380 \mathrm{bp}$ and the smaller $\mathrm{Na}_{\mathrm{V}} 1.5 \mathrm{a}$ isoform of $218 \mathrm{bp}$, which lacked exon 18, were detected in all three tissues. Expression of the $\mathrm{Na}_{\mathrm{V}} 1.5 \mathrm{a}$ isoform was stronger than the larger $\mathrm{Na}_{\mathrm{V}} 1.5 \mathrm{c}$ isoform in gut tissue at both E11.5 and adult. An additional band of $~ 300$ bp was detected in E11.5 gut, with weak expression in adult gut and brain. This band could correspond to a partial deletion of exon 18. Additional bands were also detected in gut tissue using primers designed to $\mathrm{Na}_{\mathrm{V}} 1.6$, which may reflect alternative splicing within the amplified exons in gut but not brain.

\section{Graded active potentials and the development of action potentials at E11.5 and E12.5}

Active membrane potential depolarizations with a rate of rise $<20 \mathrm{mV} / \mathrm{ms}$ were termed GAPs and were recorded from some E11.5 and E12.5 cells. Two different types of GAPs were observed: (1) slow-GAPs, which did not appear to be carried by a $\mathrm{Na}^{+}$ current; and (2) fast-GAPs, which appeared to be transitional events between slow-GAPs and APs (Fig. 7A). Fast-GAPs were difficult to define, as they were similar in shape to APs, but with slower rise times, smaller amplitudes, and longer durations than
APs (Fig. 7B). To analyze GAPs, we calculated the amplitude of the "active component" of the response to the $1 \mathrm{~ms}$ depolarizing current step (Fig. 7A'). When the APs were combined with GAPs, the amplitudes of the active components formed a continuous spectrum, with slow-GAPs at one end and adult-like APs at the other (Fig. 7B). The properties of immature single firing APs were difficult to distinguish from some of the fast-GAPs (Fig. $7 B$, inset). However, as indicated above, we made a distinction between APs and GAPs at the rate of rise of $20 \mathrm{mV} / \mathrm{ms}$ based on the ability of APs to overshoot $0 \mathrm{mV}$ when stimulated from a baseline membrane potential of $\sim-65 \mathrm{mV}$. Some GAPs with a rate of rise between 15-20 mV/ms also overshot $0 \mathrm{mV}$, but mostly from more hyperpolarized holding potentials $(<-70 \mathrm{mV})$.

A fast inward current was observed in both slow-GAP and fast-GAP cells when depolarized from a holding potential of -70 $\mathrm{mV}$ in voltage-clamp. The current-voltage relationship of the inward current appeared similar in slow-GAP and fast-GAP cells compared with AP-firing cells (Fig. 7C). To estimate the activation kinetics of the channel responsible for the inward current, the $10-90 \%$ rise time was calculated for the inward current when cells were depolarized to $-10 \mathrm{mV}$ (Table 1). The rise time was similar in all three cell types. The reversal potentials of the inward current of slow- and fast-GAPs were found to be positive values (Table 1), indicating that both are carried by inward cation currents. The voltage dependence of activation for slow- and fastGAP cells appeared to be very similar to each other (Fig. $7 C^{\prime}$; Table 1). To investigate whether tetrodotoxin (TTX)-sensitive VGSCs were responsible for these active responses, TTX ( $1 \mu \mathrm{M})$ was applied to all cells. All embryonic APs were blocked by TTX; however, a small active component remained that resembled a slow-GAP $(n=5$, Fig. $7 D)$. TTX had no effect on slow-GAPs $(n=$ 5/5). To examine whether TTX-resistant VGSCs were involved, lidocaine (1 mM) was also applied. However, neither lidocaine, nor lidocaine in combination with TTX, reduced the amplitude of the active component of the slow-GAPs $\left(n=4 / 4\right.$, Fig. $\left.7 D^{\prime}\right)$. The properties of fast-GAP cells were not included in this comparison as fast-GAP cells shared properties that overlapped with both groups. Furthermore, there was substantial variability in the amplitude of the fast-GAPs under drug-free control conditions, which made it difficult to distinguish whether or not a change in the amplitude was due to the addition of $\mathrm{Na}^{+}$channel blockers. 
A slow-GAP
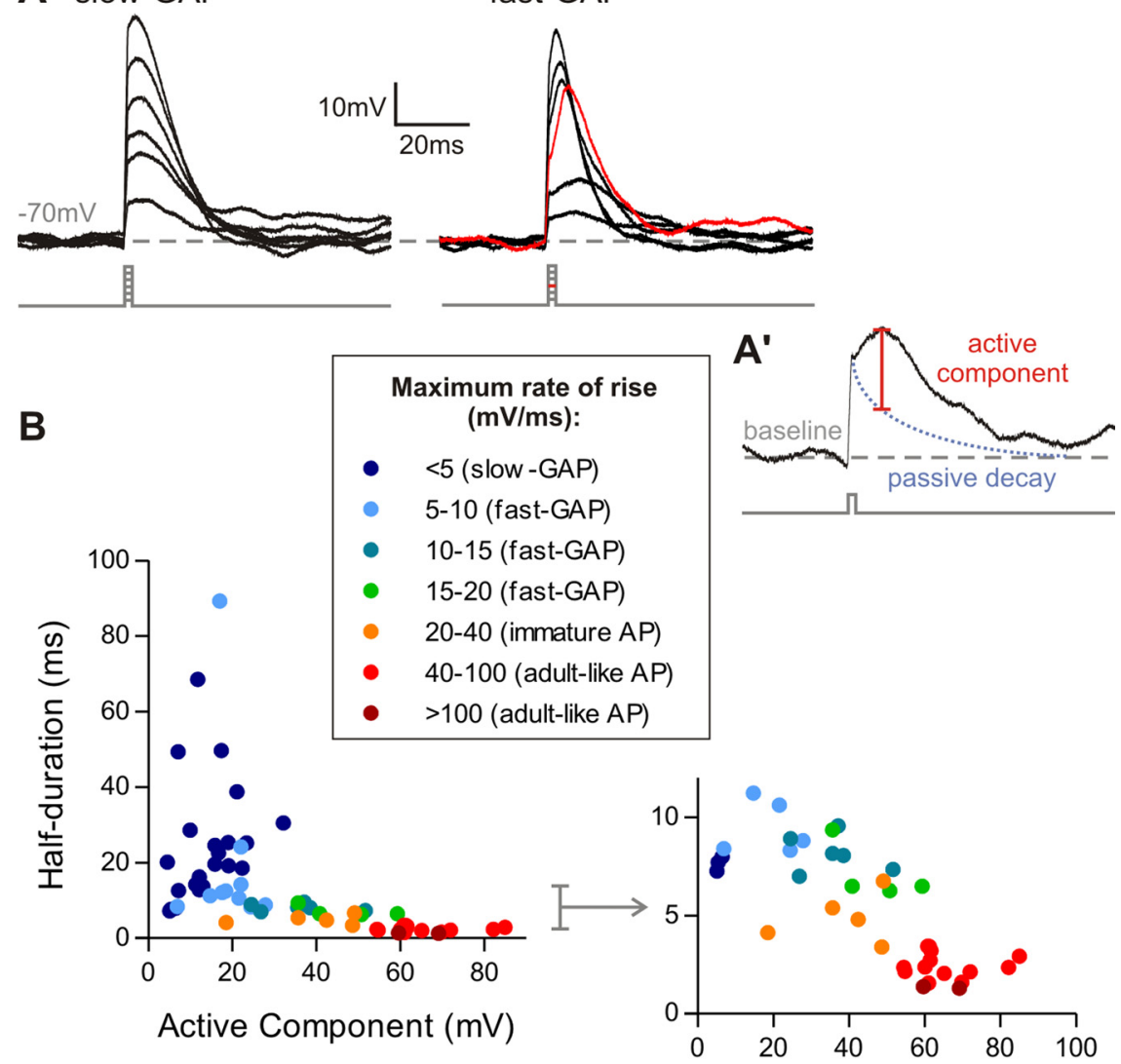

C
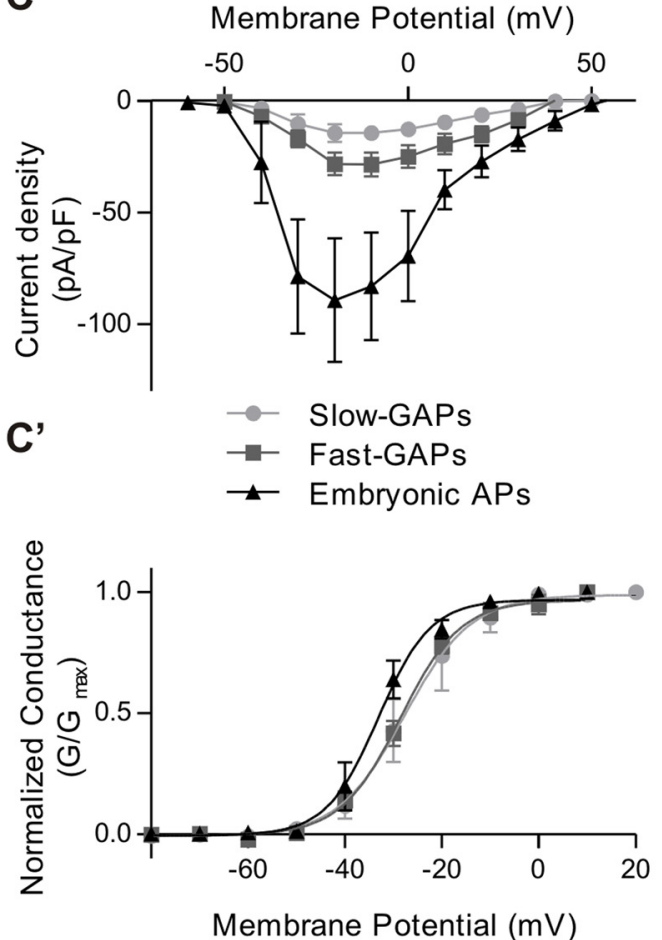

Figure 7. GAPs were observed in embryonic cells as immature active responses and are driven in part by a TTX and lidocaine insensitive current. $\boldsymbol{A}$, Representative traces of slow-GAPs and fast-GAPs from E11.5 when stimulated with incremental $1 \mathrm{~ms}$ depolarizing current steps (gray traces). APs could not be stimulated in these cells even with large amplitude current pulses that depolarized the membrane potential to $0 \mathrm{mV}$. The trace with the largest active component is highlighted in red. $\boldsymbol{A}^{\prime}$, The amplitude of the active component (red) was calculated by subtracting the passive decay (blue dotted trace). $\boldsymbol{B}$, The spectrum of active responses from E12.5 cells. Types of responses were grouped according to their maximum rate of rise when stimulated from
"Inactive" cells at E11.5 and E12.5

Small subpopulations of E11.5 TH-GFP ${ }^{+}$ cells $(19 \%)$ and E12.5 cells with neuronal morphology $(7 \%)$ were classified as "inactive" (Fig. 1A). These cells did not produce an active depolarization in response to a $1 \mathrm{~ms}$ depolarizing current step; however, in most cells a very small "apparent active" response was observed in response to $500 \mathrm{~ms}$ depolarizing current steps $(67 \%, n=10 / 15)$. In voltage-clamp studies, all cells exhibited an outward current $(n=10 / 10)$ in response to depolarization. Indeed, in all cells, large depolarizations to $0 \mathrm{mV}$ showed signs of activation of a repolarizing voltage-gated $\mathrm{K}^{+}$channel, as the decay to resting membrane potential was actually faster than predicted for passive decay. An inward current in response to depolarization was observed in some of these cells $(n=3 / 10)$. In these cells, there appeared to be a small active component in response to the $1 \mathrm{~ms}$ current step; however, the membrane potential never increased above that of the initial passive depolarization. Compared with the properties of other active embryonic cells, these inactive cells had significantly more depolarized RMPs $(-39 \pm 3.7 \mathrm{mV}, n=$ 16 , vs $-47 \pm 1.3 \mathrm{mV}, n=100$ for active cells; $p<0.05)$, larger capacitances $(9.6 \pm$ $2.3 \mathrm{pF}, n=18$, vs $5.0 \pm 0.2 \mathrm{pF}, n=103$; $p<0.05)$, and lower input resistances $(1.9 \pm 0.8 \mathrm{G} \Omega, n=3$, vs $5.7 \pm 0.3 \mathrm{G} \Omega, n=$ $44 ; p<0.05$; Mann-Whitney test for all). There was no difference in the membrane time constant $(29 \pm 6.5 \mathrm{~ms}, n=18$, vs $22 \pm 1.4 \mathrm{~ms}, n=103$; $p=0.63$, MannWhitney test).

\section{The development of $\mathrm{AH}$ and $\mathrm{S}$} electrophysiological properties $\mathrm{AH}$ and $\mathrm{S}$ electrophysiological classes of neurons could be distinguished in freshly dissociated cultures of adult enteric neurons in this study, as $\mathrm{AH}$ neurons had an inflection on the repolarizing phase of

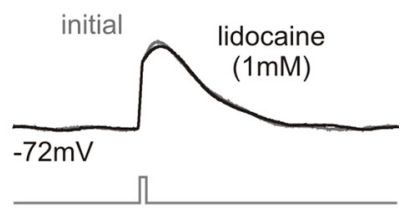

$-65 \mathrm{mV}$. Slow-GAPs were the most immature responses with a small active component and large half-duration. The $y$-scale is expanded in the inset. As the maximum rate of rise increased, the active component amplitude also increased and the half-duration decreased. $C_{,} \mathbf{C}^{\prime}$, When depolarized from a holding membrane potential of $-70 \mathrm{mV}$, an inward current was also observed in slow-GAP and fast-GAP cells. The currents in these cells followed a similar current-voltage relationship compared with AP-firing cells (C); however, the voltage dependence of activation appeared to differ between GAP and AP-firing cells $\left(\boldsymbol{C}^{\prime}\right) . \boldsymbol{D}, \boldsymbol{D}^{\prime}$, Representative responses of AP-firing cells to $\Pi X(\boldsymbol{D})$ and slow-GAP cells to lidocaine $\left(\boldsymbol{D}^{\prime}\right)$ at E12.5. For APfiring cells, a small active component remained in the presence of $T X$ (arrow) 
Table 1. Properties of the inward current in GAP and embryonic AP-firing cells

\begin{tabular}{lccc}
\hline Firing type & Slow-GAP & Fast-GAP & Embryonic AP \\
\hline Rise time (10-90\%) & $0.34 \pm 0.03 \mathrm{~ms}, n=3$ & $0.34 \pm 0.03 \mathrm{~ms}, n=9$ & $0.26 \pm 0.02 \mathrm{~ms}, n=8$ \\
Reversal potential & $+51 \pm 11 \mathrm{mV}, n=3$ & $+57 \pm 8.5 \mathrm{mV}, n=10$ & $+46 \pm 3.2 \mathrm{mV}, n=8$ \\
Voltage-dependence of activation & $5.9 \pm 0.5, n=3$ & $5.7 \pm 0.3, n=10$ & $4.1 \pm 0.6, n=8$ \\
$\quad$ Slope factor & $-27 \pm 4.1 \mathrm{mV}, n=3$ & $-28 \pm 1.3 \mathrm{mV}, n=10$ & $-33 \pm 2.0 \mathrm{mV}, n=8$ \\
$\quad$ Voltage of half-activation & & & \\
\hline
\end{tabular}

their AP ( $n=12 / 15$; Fig. $8 A)$, and S neurons did not $(n=3 / 15$; Hirst et al., 1974; Bornstein et al., 1994). The inflection was identified in the time derivative of the AP during repolarization (Fig. 8 A) (Clerc et al., 1998). The proportions of AH and S cells sampled in this study differ from those found in situ (Nurgali et al., 2004) as we targeted large neurons to analyze the properties of AH cells. We were able to record the current underlying the slow afterhyperpolarizing potential $\left(I_{\mathrm{SAHP}}\right)$ in $\mathrm{AH}$ neurons in voltageclamp, by applying two successive voltage ramps of $5 \mathrm{~s}$ duration from $-120 \mathrm{mV}$ to $-10 \mathrm{mV}$, with a $2 \mathrm{~s}$ interval (Fig. $8 \mathrm{~B}$ ). The sAHP was also investigated in current-clamp mode, by stimulation of APs using a $500 \mathrm{~ms}$ depolarizing current pulse. Unlike previous studies of the guinea pig and also whole-cell patch recordings from mouse myenteric neurons in situ (Rugiero et al., 2002; Mao et al., 2006), several action potentials were required to activate a detectable sAHP.

The majority of AP-firing cells at E11.5 and E12.5 did not possess an sAHP or the inflection during AP repolarization ( $\mathrm{Ta}-$ ble 2). These properties were first seen at $\mathrm{P} 0 / \mathrm{P} 1$, and many neurons at $\mathrm{P} 0 / \mathrm{P} 1$ exhibited an inflection $(n=11 / 14$; Fig. $8 C)$. Again, this proportion was not a representative sample as we targeted large neurons. A very small sAHP was observed in two P0/P1 neurons, but only after many APs had fired (Fig. $8 D$ ). The $I_{\text {sAHP }}$ was not observed in any $\mathrm{P} 0 / \mathrm{P} 1$ cells using the voltage-clamp technique. A hyperpolarization-activated $\mathrm{H}$-current $\left(I_{\mathrm{h}}\right)$, which is often present in myenteric $\mathrm{AH}$ neurons, was observed in 5 of 12 cells at $\mathrm{P} 0 / \mathrm{P} 1$. Two of these had a prominent $I_{\mathrm{h}}$ (Fig. $8 E$ ), while three had a very small $I_{\mathrm{h}}$ sag. In voltage-clamp mode, P0/P1 cells often did not produce a stable response to hyperpolarization. An $\mathrm{H}$-current was only recorded from 1 out of 7 P0/P1 cells (Fig. $\left.8 E^{\prime}\right)$. Thus, it appears that the inflection on AP repolarization develops between E12.5 and P0; the $I_{\mathrm{h}}$ begins to develop at P0, while the sAHP develops postnatally. Interestingly, we observed two cells at E11.5 that exhibited an inflection (Fig. $8 F$ ), and an $I_{\mathrm{h}}$ in one cell at E12.5 (Fig. $8 F^{\prime}$ ). Accordingly, it is possible that a small number of cells begin to develop some of these characteristics before birth.

\section{The development of fast excitatory synaptic potential-like activity}

Spontaneous changes in membrane potential that resembled fast excitatory synaptic potential (fEPSPs) were observed in some cells with neuronal morphology at E12.5 (Fig. 9A). These events were observed in both AP-firing $(n=4)$ and GAP cells $(n=9)$. Because their occurrence was highly variable, pharmacological analysis of these events was not attempted. When compared with fEPSPs observed in adult $S$ neurons (Fig. 9B), the rise time in E12.5 cells was more prolonged $(16.3 \pm 1.5 \mathrm{~ms}, n=61$ for E12.5, vs $11.0 \pm 2.6 \mathrm{~ms}, n=22$ for adults; $p<0.001$, Mann-Whitney test). There was no significant difference in the decay time $(63 \pm$ $6.9 \mathrm{~ms}, 54 \pm 9.1 \mathrm{~ms} ; p=0.63)$ or the amplitude $(13.7 \pm 1.3 \mathrm{mV}$, $10.2 \pm 1.4 \mathrm{mV} ; p=0.16$; Mann-Whitney test for both) of these fEPSP-like events between E12.5 and adult. fEPSP-like events were more difficult to detect at E11.5 as the membrane potential was less stable and large fluctuations were often present; however, four distinct events that resembled fEPSPs were observed in two cells.

There are a number of explanations for how fEPSP-like events are triggered in acutely dissociated cultured cells. To determine whether there were any boutons associated with the cell bodies, E12.5 small intestine was dissociated, cultured for 4 or $7 \mathrm{~h}$, and then processed for immunohistochemistry using antibodies to the synaptic vesicle protein, synaptophysin, the pan-neuronal marker, $\mathrm{Hu}$, and neuron-specific class III tubulin (Tuj1). Synaptophysin-immunoreactivity was found in $\mathrm{Hu}^{+}$cell bodies (Fig. 9C). Even after $4 \mathrm{~h}$ in culture, some $\mathrm{Hu}^{+}$neurons gave rise to short Tuj $1^{+}$neurites that possessed one or more synaptophy$\sin ^{+}$boutons (data not shown). Synaptophysin ${ }^{+}$bouton-like structures were observed closely apposed to some $\mathrm{Hu}^{+}$cell bodies (Fig. 9C). In most cases, it was not possible to determine whether these were synaptic boutons that had been present in vivo and remained adhered to the cell body after the dissociation process, or were newly formed synapses. The presence of synaptophysin immunoreactivity in the cell bodies also raises the possibility that neurotransmitters are directly released from the soma, which has been observed in dorsal root ganglion neurons (Huang and Neher, 1996). In these cells, somatic release can trigger autocrine or paracrine responses.

\section{Discussion}

There is strong evidence that neural activity is present at early stages of the embryonic ENS as it plays important roles in guiding many developmental processes (Vohra et al., 2006; Hao et al., 2010; Li et al., 2010, 2011). We recently showed that $\sim 40 \%$ of cells with pan-neuronal markers in the gut of E11.5 mice respond to electrical stimulation with an increase in intracellular $\mathrm{Ca}^{2+}$ (Hao et al., 2011). However, before the present work, it was unknown whether the electrophysiological properties of embryonic enteric "neurons" are the same as those of mature enteric neurons, and whether all ENCCs that express pan-neuronal markers in the embryonic gut are electrically active. In this study, we have used whole-cell patch-clamp recordings to demonstrate that E11.5 ENCCs expressing neuronal markers include (1) cells that are capable of firing APs with similar properties to those of adult enteric neurons, (2) cells that exhibit GAPs rather than true APs, and (3) cells that do not exhibit any evidence of excitability. The presence of a significant proportion of cells firing adult-like APs as early as E11.5 highlights the possibility that they influence later developmental events such as network formation.

\section{APs in embryonic enteric neurons}

All APs in embryonic neurons appeared to be driven by a TTXsensitive voltage-gated $\mathrm{Na}^{+}$current. Our voltage-clamp studies showed that these embryonic AP-firing cells had inward currents with the same current-voltage relationship and voltage dependence of activation as those of inward currents in P0/P1 neurons. In addition, we have shown using RT-PCR that several VGSCs are expressed in the gut at E11.5, although as these studies were per- 

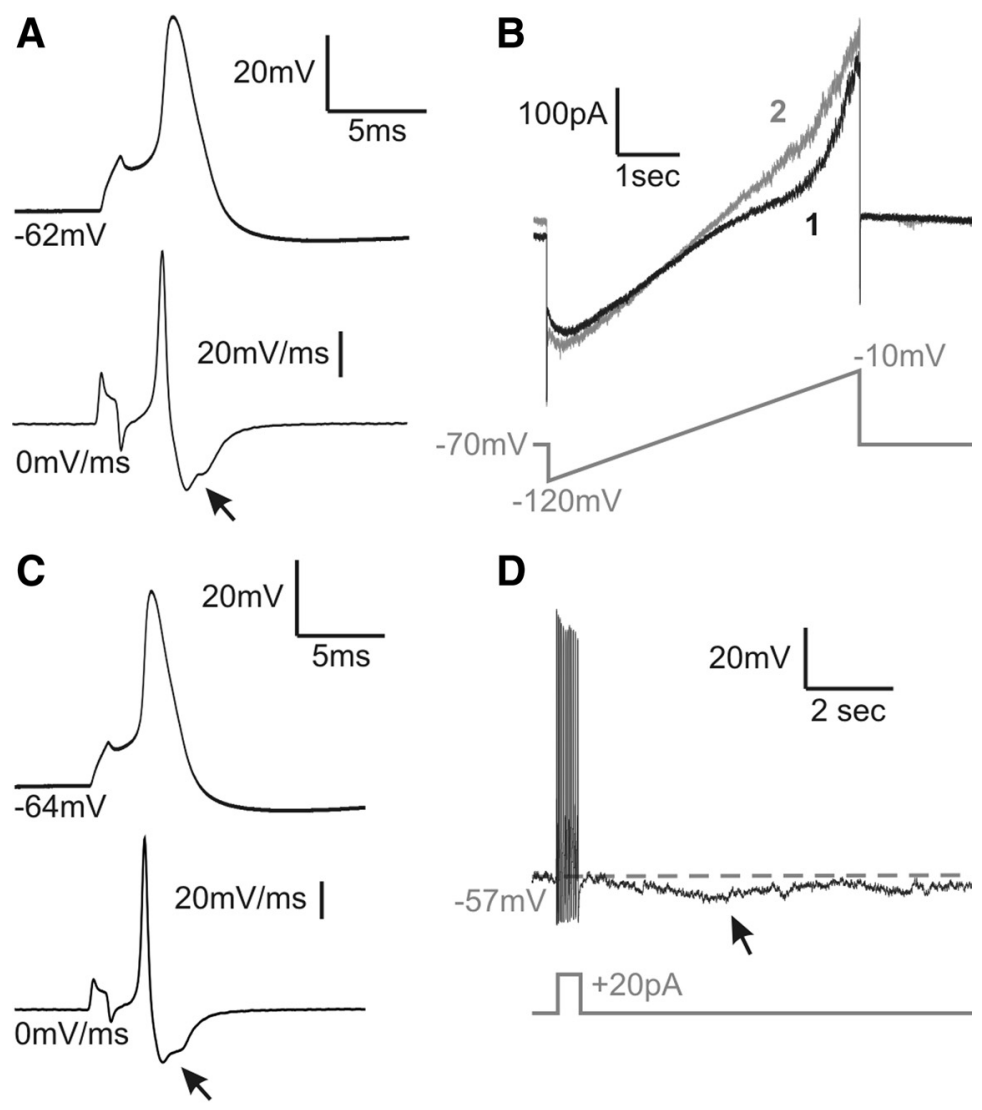

D

E

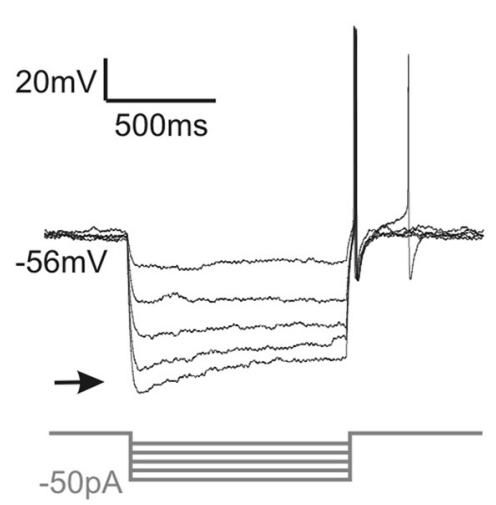

$\mathbf{F}$

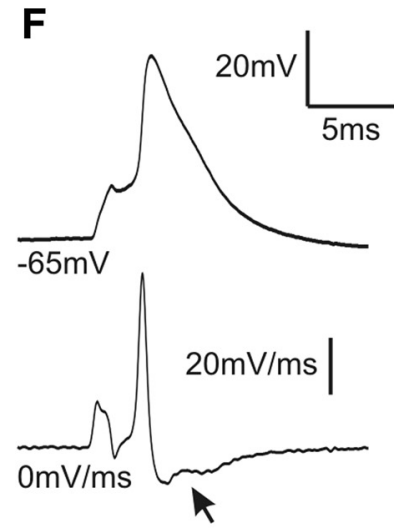

$E^{\prime}$
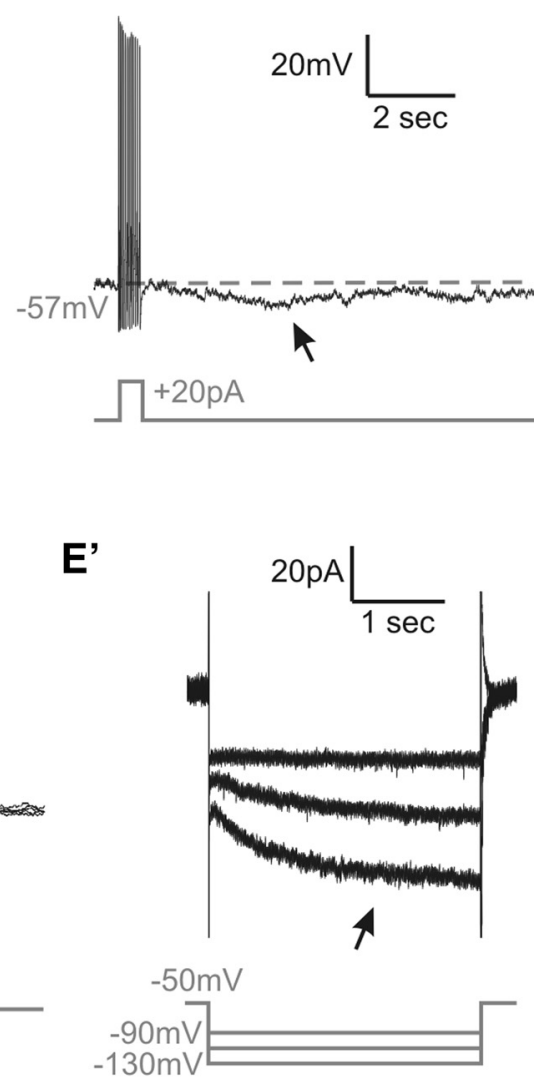

$\mathbf{F}^{\prime}$
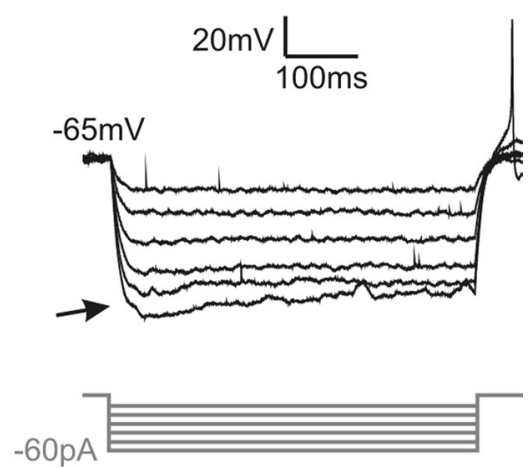

Figure 8. The development of AH properties. AH properties were recorded in adult enteric neurons $(\boldsymbol{A}, \boldsymbol{B})$ and some properties at P0/P1 $\left(\boldsymbol{C}-\boldsymbol{E}^{\prime}\right)$ as well as in embryonic cells $\left(\boldsymbol{F}, \boldsymbol{F}^{\prime}\right)$. $\boldsymbol{A}$, AH neurons typically had a hump component to the AP (top trace), which was detected in the first derivative of the AP (bottom trace) as an inflection on the repolarizing phase (arrow). $\boldsymbol{B}$, The $I_{\text {SAHP }}$ was recorded in voltage-clamp mode by applying two consecutive ramps with a 2 s interval, and observed as a difference between the

formed on the entire gut, we cannot rule out the possibility that some could be expressed by non-ENCCs. Expression of $\mathrm{Na}_{\mathrm{v}} 1.5$ has been identified in human jejunal smooth muscle cells and interstitial cells of Cajal (ICC) (Holm et al., 2002; Ou et al., 2002; Strege et al., 2003), and it is possible that mRNA from the common precursors of muscle and ICC contributed to the expression of $\mathrm{Na}_{\mathrm{v}} 1.5$ detected in this study. Increasing VGSC expression during development is most likely responsible for maturation of APs, as we observed increases in the $\mathrm{Na}^{+}$current density through development. This has also been documented in other parts of the developing nervous system and also during the differentiation of adult neural stem cells (Picken Bahrey and Moody, 2003; Schmidt-Hieber et al., 2004; Moe et al., 2005; Walsh et al., 2009). The ENS is one of the earliest parts of the nervous system to have mature forms of neural activity (Picken Bahrey and Moody, 2003; McKay and Turner, 2005; Lechner et al., 2009; Walsh et al., 2009). Although the significance of the ability to fire adultlike APs at such early stages of ENS development is unclear, they are likely to have important implications for the correct development of neuronal circuits in the gut (Vohra et al., 2006; Hao et al., 2010).

Graded active responses were present at E11.5 and E12.5, but not at P0/P1 or adult

There has been recent debate as to when an active electrical response can be called an "AP," and it has been argued that APs must be self-sustaining and selfterminating events that do not vary with the amplitude, duration, or waveform of the stimulus (Lockery et al., 2009). SlowGAPs recorded from embryonic ENCCs with neuronal markers clearly differed from APs in shape and did not appear to be carried by a $\mathrm{Na}^{+}$current as they were unaffected by TTX or lidocaine. These slow-GAPs may be driven by a voltagegated $\mathrm{Ca}^{2+}$ current, as $\mathrm{Ca}^{2+}$-driven activity precedes $\mathrm{Na}^{+}$-driven events in other developing neurons (Spitzer and Baccaglini, 1976; Gust et al., 2003). However, it

\section{$\leftarrow$}

trace 1 (black trace) and 2 (gray trace). C, The inflection in P0/P1 APs (arrow). D, sAHP at P0/P1 (arrow) recorded in current clamp following the firing of multiple APs. $E$, $I_{h}$ (arrow) recorded in current clamp by long-duration hyperpolarizing current steps. $\boldsymbol{E}^{\prime}, I_{\mathrm{h}}$ (arrow) in voltage-clamp. $\boldsymbol{F}$, The inflection was recorded two cells at E11.5 (arrow). $\boldsymbol{F}^{\prime}$, An $I_{\mathrm{h}}$ recorded from an $\mathrm{E} 12.5$ cell. 
is also possible that some TTX-insensitive $\mathrm{Na}^{+}$channels or embryonic forms of some $\mathrm{Na}^{+}$channels lack lidocaine sensitivity. The fast-GAPs were more difficult to characterize as they resembled APs in shape, but were too variable in amplitude and duration in response to changing stimulus parameters to be classified as APs. It was not technically possible to examine the currents that underlie the fast-GAPs. They probably include a $\mathrm{Na}^{+}$current, as there was clear overlap in the amplitudes and durations of the active components in the populations of fast-GAP firing and APfiring cells. The spectrum of GAPs and APs in embryonic neurons that we observed probably reflects varying stages of neuronal maturation, with slow-GAP neurons representing cells with no significant VGSC expression, fast-GAP neurons with low levels of VGSC expression, and AP-firing neurons having sufficient VGSC expression to produce all-or-nothing events with further increases in expression leading to the more adult-like APs seen in some E11.5 and E12.5 cells. Increases in $\mathrm{Na}^{+}$current density have been described for other developing neurons (O'Dowd et al., 1988; Rothe et al., 1999; Picken Bahrey and Moody, 2003; Fry, 2006). Future biophysical studies are required to reveal whether fast-GAPs actively propagate and, thus, signal along the cell's neurite or axon.

\section{Cells expressing neuronal markers and morphology without functional properties of neurons}

A small proportion of TH-GFP ${ }^{+}$cells and embryonic ENCCs with neuronal morphology did not produce an active response upon depolarization, and most of these cells did not exhibit an inward current. Hence, it appears that expression of pan-neuronal markers precedes the expression of voltagegated ion channels responsible for neuronal excitability. During the differentiation of adult neural stem cells, pan-neuronal markers also appear before the induction of active membrane properties (Moe et al., 2005). This highlights the importance of conducting physiological experiments, and not relying on the expression of neuronal markers, to determine whether functional neurons have been generated from stem/progenitor cells in transplantation studies.

\section{fEPSP-like events}

Our data suggest that excitable embryonic ENCCs receive fast synaptic input. Apparent spontaneous fEPSPs were recorded from E11.5, E12.5, P0/P1, and adult S neurons. fEPSP-like events in E12.5 cells had 50\% longer rise times than fEPSPs in adult $S$ neurons, which may be due to changes in membrane time constant or differences in the properties of the postsynaptic receptors. The fact that decay times were not different suggests that the latter is the more probable explanation. The presence of fEPSPlike events supports recent studies that imply neurotransmitter release occurs during ENS development (Li et al., 2011). Our immunohistochemical data using antibodies to the synaptic vesicle protein, synaptophysin, suggest that fEPSP-like events might body. Scale bar, $5 \mu \mathrm{m}$.
Table 2. The development of AH neuron characteristics

\begin{tabular}{llll}
\hline Age & Inflection & $I_{\mathrm{h}}$ & sAHP \\
\hline E11.5 & $n=2 / 11$ & $n=0 / 6$ & $n=0 / 9$ \\
E12.5 & $n=0 / 24$ & $n=1 / 6$ & $n=0 / 11$ \\
P0/P1 & $n=11 / 14$ & $n=5 / 12$ & $n=2 / 14^{*}$ \\
\hline
\end{tabular}

Number of cells observed with each property out of the total number of AP-firing cells examined. *An sAHP was only observed following the firing of multiple APs.

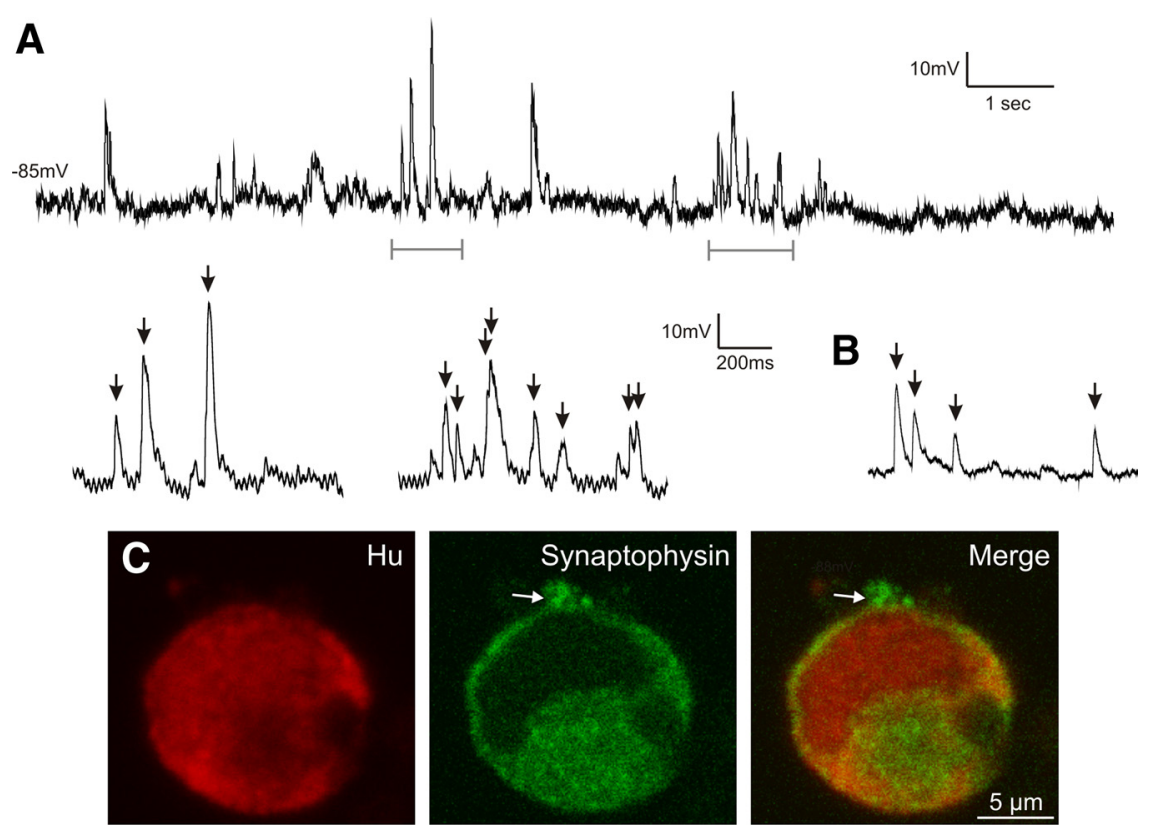

Figure 9. Spontaneous fEPSP-like events in embryonic cells. $\boldsymbol{A}, \boldsymbol{B}$, Representative traces from a fast-GAP cell at E12.5 $(\boldsymbol{A})$, close-ups (gray bars) are magnified below. fEPSP-like events (arrows) appeared similar to adult fEPSPs (arrows, $\boldsymbol{B}$ ), when shown on the same scale. $\mathrm{C}$, Single optical section through a $\mathrm{Hu}^{+}$ENCC dissociated from E12.5 small intestine and cultured for $4 \mathrm{~h}$ Synaptophysin-immunoreactivity is visible in the $\mathrm{Hu}^{+}$cell body and in a bouton-like structure (arrow) closely apposed to the cell

be elicited by several mechanisms: (1) axon terminals that remained adhered to neurons during dissociation; (2) de novo synapses that formed during culture; and (3) release of neurotransmitters from the cell soma (Huang and Neher, 1996). In addition, neurotransmitters may be released spontaneously from growth cones, both in vivo and in culture, before mature synapse formation (Demarque et al., 2002).

\section{Development of $\mathrm{AH}$ and $\mathrm{S}$ enteric neuron subtypes}

The postnatal development of the electrophysiological and morphological properties of AH and S neurons, the two major electrophysiological classes of enteric neurons in the adult, has recently been characterized (Foong et al., 2012). Consistent with the current study, postnatal maturation of the sAHP was reported by Foong et al. (2012). However, the prominent afterdepolarizing potential observed by Foong et al. (2012), who used conventional intracellular recording techniques, was not seen in $\mathrm{P} 0 / \mathrm{P} 1$ neurons in this present study. This is probably due to differences in the tissue preparation and/or recording techniques. Early electrical activity is vital for guiding neuronal development and network formation elsewhere in the nervous system (Ben-Ari and Spitzer, 2010). Thus, a major role for embryonic enteric neuron signaling may be regulating the properties of later developing enteric neurons (Li et al., 2010, 2011), and events such as axon pathfinding and the wiring of ENS circuits. More complex signaling mechanisms such as the 
sAHP are important in the mature nervous system (Thomas and Bornstein, 2003; Chambers et al., 2011), but do not appear to play any roles in embryonic development as they appear postnatally.

\section{Conclusions}

Our study suggests that the development of enteric neurons proceeds through distinct steps. First, neuron precursors express pan-neuronal markers without exhibiting the functional properties of neurons. Second, the cells begin expressing a TTX-insensitive voltage-gated inward current that allows them to fire GAPs. Third, TTX-sensitive voltage-gated $\mathrm{Na}^{+}$ channels begin to be expressed and when they reach sufficient density, the cells become AP-firing, and are then true neurons. Finally, after birth there is further maturation in electrophysiological properties, with the development of a sAHP and a hump during AP repolarization in a subpopulation of enteric neurons. The demonstration of neural activity in the embryonic ENS is an essential underpinning to previous studies showing that neurotransmitters influence enteric neuron development and raises the possibility that neural activity influences the wiring of the ENS.

\section{References}

Baetge G, Gershon MD (1989) Transient catecholaminergic (TC) cells in the vagus nerves and bowel of fetal mice: relationship to the development of enteric neurons. Dev Biol 132:189-211.

Ben-Ari Y, Spitzer NC (2010) Phenotypic checkpoints regulate neuronal development. Trends Neurosci 33:485-492.

Bornstein JC, Furness JB, Kunze WA (1994) Electrophysiological characterization of myenteric neurons: how do classification schemes relate? J Auton Nerv Syst 48:1-15.

Chambers JD, Bornstein JC, Thomas EA (2011) Multiple neural oscillators and muscle feedback are required for the intestinal fed state motor program. PLoS One 6:e19597.

Clerc N, Furness JB, Bornstein JC, Kunze WA (1998) Correlation of electrophysiological and morphological characteristics of myenteric neurons of the duodenum in the guinea-pig. Neuroscience 82:899-914.

Demarque M, Represa A, Becq H, Khalilov I, Ben-Ari Y, Aniksztejn L (2002) Paracrine intercellular communication by $\mathrm{a} \mathrm{Ca}^{2+}$ - and SNAREindependent release of GABA and glutamate prior to synapse formation. Neuron 36:1051-1061.

Fairman CL, Clagett-Dame M, Lennon VA, Epstein ML (1995) Appearance of neurons in the developing chick gut. Dev Dyn 204:192-201.

Foong JP, Nguyen TV, Furness JB, Bornstein JC, Young HM (2012) Myenteric neurons of the mouse small intestine undergo significant electrophysiological and morphological changes during postnatal development. J Physiol 590:2375-2390.

Fry M (2006) Developmental expression of $\mathrm{Na}^{+}$currents in mouse Purkinje neurons. Eur J Neurosci 24:2557-2566.

Furness JB (2006) The enteric nervous system. Oxford: Blackwell.

Gershon MD (2010) Developmental determinants of the independence and complexity of the enteric nervous system. Trends Neurosci 33:446-456.

Gust J, Wright JJ, Pratt EB, Bosma MM (2003) Development of synchronized activity of cranial motor neurons in the segmented embryonic mouse hindbrain. J Physiol 550:123-133.

Hao MM, Anderson RB, Kobayashi K, Whitington PM, Young HM (2009) The migratory behavior of immature enteric neurons. Dev Neurobiol 69:22-35.

Hao MM, Moore RE, Roberts RR, Nguyen T, Furness JB, Anderson RB, Young HM (2010) The role of neural activity in the migration and differentiation of enteric neuron precursors. Neurogastroenterol Motil 22:e127-e137.

Hao MM, Boesmans W, Van den Abbeel V, Jennings EA, Bornstein JC, Young HM, Vanden Berghe PV (2011) Early emergence of neural activity in the developing mouse enteric nervous system. J Neurosci 31:15352-15361.

Heanue TA, Pachnis V (2007) Enteric nervous system development and
Hirschsprung's disease: advances in genetic and stem cell studies. Nat Rev Neurosci 8:466-479.

Hille B (2001) Classical biophysics of the giant squid axon. In: Ion channels of excitable membranes, pp 25-60. Sunderland, MA: Sinauer.

Hirst GD, Holman ME, Spence I (1974) Two types of neurones in the myenteric plexus of duodenum in the guinea-pig. J Physiol 236:303-326.

Hodgkin AL, Huxley AF (1952) A quantitative description of membrane current and its application to conductance and excitation in nerve. J Physiol 117:500-544.

Holm AN, Rich A, Miller SM, Strege P, Ou Y, Gibbons S, Sarr MG, Szurszewski JH, Rae JL, Farrugia G (2002) Sodium current in human jejunal circular smooth muscle cells. Gastroenterology 122:178-187.

Huang LY, Neher E (1996) $\mathrm{Ca}^{2+}$-dependent exocytosis in the somata of dorsal root ganglion neurons. Neuron 17:135-145.

Kapur RP, Yost C, Palmiter RD (1992) A transgenic model for studying development of the enteric nervous system in normal and aganglionic mice. Development 116:167-175.

Kerr NC, Holmes FE, Wynick D (2004) Novel isoforms of the sodium channels $\mathrm{Na}_{\mathrm{V}} 1.8$ and $\mathrm{Na}_{\mathrm{V}} 1.5$ are produced by a conserved mechanism in mouse and rat. J Biol Chem 279:24826-24833.

Lechner SG, Frenzel H, Wang R, Lewin GR (2009) Developmental waves of mechanosensitivity acquisition in sensory neuron subtypes during embryonic development. EMBO J 28:1479-1491.

Le Douarin NM, Teillet MA (1973) The migration of neural crest cells to the wall of the digestive tract in avian embryo. J Embryol Exp Morphol 30:31-48.

Li Z, Caron MG, Blakely RD, Margolis KG, Gershon MD (2010) Dependence of serotonergic and other nonadrenergic enteric neurons on norepinephrine transporter expression. J Neurosci 30:16730-16740.

Li Z, Chalazonitis A, Huang YY, Mann JJ, Margolis KG, Yang QM, Kim DO, Côté F, Mallet J, Gershon MD (2011) Essential roles of enteric neuronal serotonin in gastrointestinal motility and the development/survival of enteric dopaminergic neurons. J Neurosci 31:8998-9009.

Lockery SR, Goodman MB, Faumont S (2009) First report of action potentials in a C. elegans neuron is premature. Nat Neurosci 12:365-366.

Mao Y, Wang B, Kunze W (2006) Characterization of myenteric sensory neurons in the mouse small intestine. J Neurophysiol 96:998-1010.

McKay BE, Turner RW (2005) Physiological and morphological development of the rat cerebellar Purkinje cell. J Physiol 567:829-850.

Moe MC, Varghese M, Danilov AI, Westerlund U, Ramm-Pettersen J, Brundin L, Svensson M, Berg-Johnsen J, Langmoen IA (2005) Multipotent progenitor cells from the adult human brain: neurophysiological differentiation to mature neurons. Brain 128:2189-2199.

Nurgali K, Stebbing MJ, Furness JB (2004) Correlation of electrophysiological and morphological characteristics of enteric neurons in the mouse colon. J Comp Neurol 468:112-124.

O'Dowd DK, Ribera AB, Spitzer NC (1988) Development of voltagedependent calcium, sodium, and potassium currents in Xenopus spinal neurons. J Neurosci 8:792-805.

Ou Y, Gibbons SJ, Miller SM, Strege PR, Rich A, Distad MA, Ackerman MJ, Rae JL, Szurszewski JH, Farrugia G (2002) SCN5A is expressed in human jejunal circular smooth muscle cells. Neurogastroenterol Motil 14:477-486.

Picken Bahrey HL, Moody WJ (2003) Early development of voltage-gated ion currents and firing properties in neurons of the mouse cerebral cortex. J Neurophysiol 89:1761-1773.

Rothe T, Jüttner R, Bähring R, Grantyn R (1999) Ion conductances related to development of repetitive firing in mouse retinal ganglion neurons in situ. J Neurobiol 38:191-206.

Rugiero F, Gola M, Kunze WA, Reynaud JC, Furness JB, Clerc N (2002) Analysis of whole-cell currents by patch clamp of guinea-pig myenteric neurones in intact ganglia. J Physiol 538:447-463.

Sasselli V, Pachnis V, Burns AJ (2012) The enteric nervous system. Dev Biol 366:64-73.

Sawamoto K, Nakao N, Kobayashi K, Matsushita N, Takahashi H, Kakishita K, Yamamoto A, Yoshizaki T, Terashima T, Murakami F, Itakura T, Okano H (2001) Visualization, direct isolation, and transplantation of midbrain dopaminergic neurons. Proc Natl Acad Sci USA 98:6423-6428.

Schmidt-Hieber C, Jonas P, Bischofberger J (2004) Enhanced synaptic plas- 
ticity in newly generated granule cells of the adult hippocampus. Nature 429:184-187.

Spitzer NC, Baccaglini PI (1976) Development of the action potential in embryo amphibian neurons in vivo. Brain Res 107:610-616.

Strege PR, Ou Y, Sha L, Rich A, Gibbons SJ, Szurszewski JH, Sarr MG, Farrugia G (2003) Sodium current in human intestinal interstitial cells of Cajal. Am J Physiol Gastrointest Liver Physiol 285:G1111G1121.

Thomas EA, Bornstein JC (2003) Inhibitory cotransmission or afterhyperpolarizing potentials can regulate firing in recurrent networks with excitatory metabotropic transmission. Neuroscience 120:333351.

Vignali S, Leiss V, Karl R, Hofmann F, Welling A (2006) Characterization of voltage-dependent sodium and calcium channels in mouse pancreatic Aand B-cells. J Physiol 572:691-706.

Vohra BP, Tsuji K, Nagashimada M, Uesaka T, Wind D, Fu M, Armon J, Enomoto H, Heuckeroth RO (2006) Differential gene expression and functional analysis implicate novel mechanisms in enteric nervous system precursor migration and neuritogenesis. Dev Biol 298: 259-271.

Walsh MA, Graham BA, Brichta AM, Callister RJ (2009) Evidence for a critical period in the development of excitability and potassium currents in mouse lumbar superficial dorsal horn neurons. J Neurophysiol 101:1800-1812.

Young HM, Newgreen D (2001) Enteric neural crest-derived cells: Origin, identification, migration, and differentiation. Anat Rec 262:1-15. 